\section{Svakt om psykopaten}

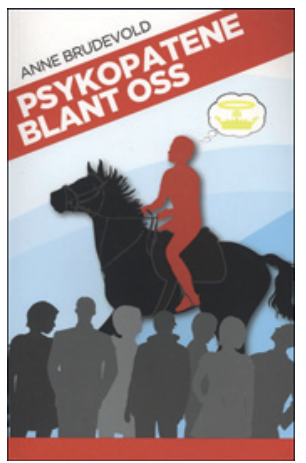

Anne Brudevold

Psykopatene blant oss

193 s. Oslo: HippieMedia, 2011.

Pris NOK 349

ISBN 978-82-998207-4-5

Psykopati og psykopatens personlighet er emner som vekker interesse og engasjement blant fag- og legfolk. De siste årene er det kommet flere bøker som beskriver psykopatens personlighet og hvordan folk må lære seg å håndtere eventuelle møter med psykopater. Denne nye boken er intet unntak. Forfatteren har ikke angitt noen spesifikke målgrupper, men ut fra helheten å bedømme er hensikten å utdanne allmennheten om hvordan de kan gjenkjenne $o g$ håndtere personer med psykopatiske personlighetstrekk. Forfatteren er utdannet både som psykolog, fysioterapeut og økonom og har flere års erfaring som privatpraktiserende psykolog.

Boken er inndelt i 11 kapitler med en naturlig progresjon og utvikling. Brudevold starter med kliniske beskrivelser av psykopaten og hvordan det må oppleves for mennesker å bli utsatt for en psykopat. Deretter beskriver hun hva som kjennetegner psykopaten, hvordan psykopatiske personlighetstrekk oppstår, de etter hvert så hyppig omtalte speilnevronene, psykopati og kriminalitet, i tillegg til psykopati som fenomen i samfunnet. Forfatteren gir et greit bilde av hvor vanskelig det er å ha med psykopater å gjøre: hvordan ofrene kan miste det meste av selvfølelsen, føle seg ubrukelige og hvordan selv sterke og velutdannede mennesker kan miste fotfeste i tilværelsen. Hun beskriver hvordan psykopaten manøvrerer og manipulerer og hvor vanskelig det kan være å bli klar over hva man i virkeligheten er utsatt for - spesielt hvis man i utgangspunktet er litt naiv, lettlurt og dumsnill.

Teksten er lettlest og enkel, men den representerer ikke noe nytt, utfordrende og spennende. Man sitter heller ikke igjen med følelsen av å ha hatt noen tankevekkende opplevelser. Det er ingen «a-haopplevelser» og «en sånn pasient har jeg hatt» eller «et sånt offer for en psykopat kjenner jeg». De klassiske psykopatikasusene som er beskrevet, er veldig nære de kasusene som er beskrevet mange ganger før.

Jeg fikk ingen god leseopplevelse. Teksten bærer preg av hastverksarbeid og inneholder en rekke skrive- og orddelingsfeil. I flere av kapitlene er det et stakkatodriv over språket med enkeltstående sitater fra personer som arbeider i feltet, iblandet sitater fra bl.a. Wikipedia. Det hele blir litt uryddig.

Emnet er viktig, og mange vil nok ha glede av å lese boken. Det finnes imidlertid mange bedre bøker om psykopati. For leger og helsepersonell anbefaler jeg boken av Dalsegg og Wesche (1). Det er en betraktelig mer informativ, leseverdig og ryddig bok om psykopati.

\section{Jan Ivar Røssberg}

Regionalt kompetansesenter for tidlig intervensjon ved psykoser TIPS Sør-Øst

Oslo universitetssykehus

\section{Litteratur}

1. Røssberg JI. Helsefarlige relasjoner. Anmeldelse av: Dalsegg A, Wesche I. Ut av psykopatens grep. Hvordan komme fri fra helsefarlige mennesker. Tidsskr Nor Legeforen 2008; 128: 1993.

\section{Helse og medisin i Danmark 1640-1840}

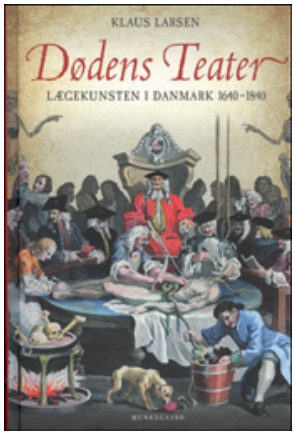

Klaus Larsen
Dødens teater

Lægekunsten i Danmark 1640-1840. 320 s, ill. København: Munksgaard Danmark, 2012.

Pris DKK 275

ISBN 978-87-628-1066-2

Klaus Larsen er til daglig journalist i Ugeskrift for Lager. I 2007 ga han sammen med historikeren Kurt Jacobsen ut boken $V e$ og velfcerd (1). I den beskriver de dansk helse- og medisinhistorie i perioden fra Sundhedskollegiet ble opprettet i København i 1803 til våre dager. Boken ble meget godt mottatt. Derfor har han nå slått til som eneforfatter for en bok om det som hendte i tiden forut, om forhistorien i det «gamle samfunn». Han begynner i 1640-årene, på Christian IVs tid, og avrunder rundt 1800, da den moderne medisinen begynte å blomstre opp, den man kan lese om i Ve og velfard.

Bortsett fra én skjønnhetsplett er resultatet blitt meget godt. Boken er svært leservennlig og levende skrevet. Teksten veksler på en medrivende måte mellom store linjer, detaljer og eksempler. Det er rikelig med gode illustrasjoner. Foran er det en tidslinje som bringer orden i årstallene, og bakerst er det et utdypende noteapparat, litteraturliste og sakregister. Boken er ryddig og god. Dansk medisinhistorie i denne tidsperioden er også norsk medisinhistorie, så dette bør være anbefalt lesning også for norske medisinstudenter.

Hva er da skjønnhetspletten? Det vites ikke om det er forfatter eller forlag som har forsynt boken med den nokså ahistoriske tittelen Dødens teater. Også formuleringen «fra vrøvl til videnskab» i baksideteksten viser den lurende tilbøyeligheten som ofte vederfares medisinhistorien, og som kan gjøre både tekster, utstillinger og museer til faglig tvilsom formidling: I sin iver etter å gjøre stoffet pirrende og sensasjonelt for vår tid, glemmer man at stoffet hører hjemme i sin egen tid. Det som for oss kan virke spektakulært, var kanskje både vanlig og forståelig i sin samtid. Helsehistorie og medisinhistorie er sjelden morsom sett $i$ sin kontekst.

Helsens og medisinens historie er, helt opp til for tre-fire generasjoner siden, fortellingen om en befolkning i konstant angst for sykdom og død, om mange med marginale levekår, om en helsehjelp som famlet, og om en vitenskap der man gjorde så godt man kunne for å skaffe ny kunnskap ut fra tidens premisser. Dette er godt beskrevet i Klaus Larsens bok. Det han omtaler, er blodig alvor i en tid fylt av avmakt. Det var f.eks. god grunn til å være hypokonder i denne fjerne tiden (s. 230)! Klaus Larsen behersker balansen mellom helse, medisin og samtid meget bra.

Forfatteren har selv brukt betegnelsen Dødens teater om offentlige henrettelser (s. 168). Det er riktig. Henrettelsene var iscenesatt teater. Hvorfor man gjorde det slik, lar seg også forklare ut fra samtiden. Men legekunsten var ikke noe dødens teater, slik tittelen kan tilsi. Tvert imot. Det var helse som var målet, selv om man sjelden oppnådde det.

\section{Øivind Larsen}

Institutt for helse og samfunn

Universitetet i Oslo

\section{Litteratur}

1. Hjort PF. Fra sykdom og nød til velferd og velstand. Anmeldelse av: Jacobsen K Larsen K. Ve og velfærd: læger, sundhed og samfund gennem 200 år. Tidsskr Nor Legeforen 2008; 128: 733. 